\title{
DOE/Nu--98007003-Reu.l
}

Nevada Test Site

Site Treatment Plan

Final Annual Update

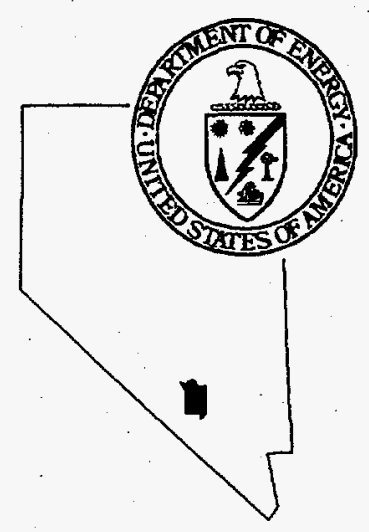

PECEIVED

JUL 161998

OSTI

April 1998

MASTEP,

Revision 1

DISTRIBUTON OF THIS DOCUMENT IS UNLMATEU

\section{Waste Management}





\section{DISCLAMMER}

This report was prepared as an account of work sponsored by an agency of the United States Government. Neither the United States Government nor any agency thereof, nor any of their employees, makes any warranty, express or implied, of assumes any legal liability or responsibility for the accuracy, completeness, or usefulness of any information, apparatus, product, or process disclosed, or represents that its use would not infringe privately owned rights. Reference herein to any specific commercial product, process, or service by trade name, trademark, manufacturer, or otherwise does not necessarily constitute or imply its endorsement, recommendation, or favoring by the United States Government or any agency thereof. The views and opinions of authors expressed herein do not necessarily state or reflect those of the United States Government or any agency thereof. 


\section{DISCLAIMER}

Portions of this document may be illegible in electronic image products. Images are produced from the best available original document. 


\section{Table of Contents}

$1.0 \quad$ Introduction $\ldots \ldots \ldots \ldots \ldots \ldots \ldots \ldots \ldots \ldots \ldots \ldots \ldots \ldots \ldots$

1.1 Purpose and Scope of the Annual Update for the Nevada Test Site--Site

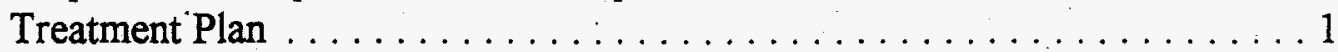

1.2 Framework for Developing the Annual Update $\ldots \ldots \ldots \ldots \ldots \ldots \ldots \ldots$

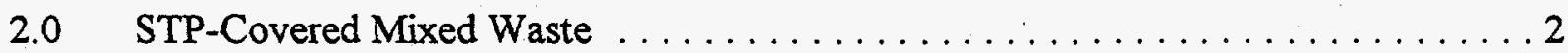

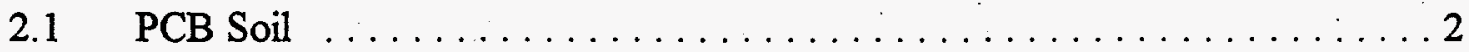

2.1.1 PCB Soil Schedule (Compactable Trash) $\ldots \ldots \ldots \ldots \ldots \ldots$

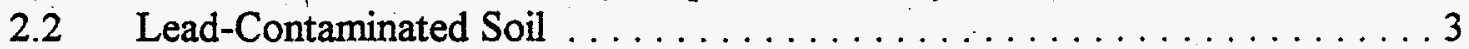

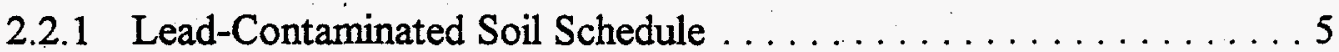

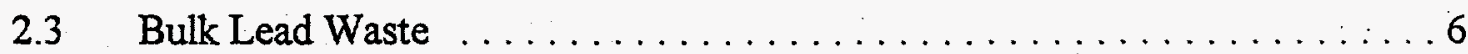

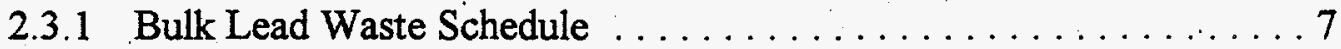

2.3.1.1 Spent Batteries Schedule $\ldots \ldots \ldots \ldots \ldots \ldots \ldots$

2.3.1.2 T2 Lead Cylinders Schedule . . . . . . . . . . . 8

2.3.1.3 Compactible Trash and PPE Schedule . . . . . . . 8

2.4 Area 12 Solvent Sludge $\ldots \ldots \ldots \ldots \ldots \ldots \ldots \ldots \ldots \ldots \ldots \ldots$

2.4.1 Area 12 Solvent Sludge Schedule . . . . . . . . . . . . . . 9

2.5 TTF Solvent . . . . . . . . . . . . . . . . . . . . . . . . .

2.5 .1 TTF Solvent Schedule . . . . . . . . . . . . . . . . . . . 10

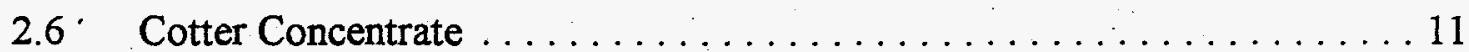

2.6.1 Cotter Concentrate (Population A) . . . . . . . . . . . . . 11

2.6.1.1 Cotter Concentrate (Population A) Schedule . . . . . . 11

2.6.2 Cotter Concentrate (Population B) . . . . . . . . . . . . . 13

2.6.2.1 Cotter Concentrate (Population B) Schedule . . . . . . 13

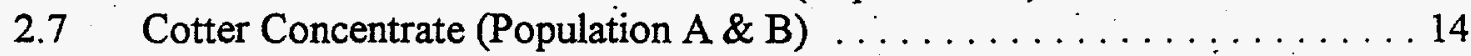

2.7.1 Revised Schedule: Cotter Concentrate (Population A \& B) . . . . 16

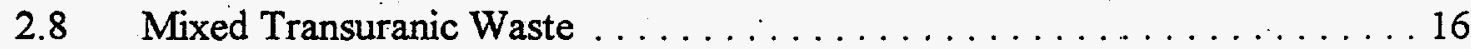

2.8.1 Mixed Transuranic Waste Schedule . . . . . . . . . . . . . . . 16

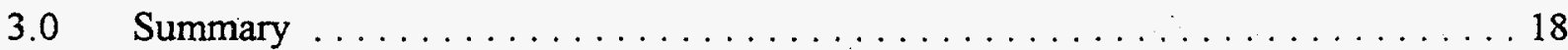




\subsection{Introduction}

A Site Treatment Plan (STP) is required for facilities at which the U.S. Department of Energy Nevada Operations Office (DOE/NV) generates or stores mixed waste (MW), defined by the Federal Facility Compliance Act (FFCAct) as waste containing both a hazardous waste subject to the Resource Conservation and Recovery Act (RCRA) and a radioactive material subject to the Atomic Energy Act. This STP was written to identify specific treatment facilities for treating DOE/NV generated MW and provides proposed implementation schedules. This STP was approved by the Nevada Division of Environmental Protection (NDEP) and provided the basis for the negotiation and issuance of the FFCAct Consent Order (CO) dated March 6, 1996. The FFCAct $\mathrm{CO}$ sets forth stringent regulatory requirements to comply with the implementation of the STP.

\subsection{Purpose and Scope of the Annual Update for the Nevada Test Site--Site Treatment Plan}

DOE/NV is required by the FFCAct CO to submit a draft annual update of the Nevada Test Site-Site Treatment Plan to NDEP for review and comment by January 15 of each year. DOE/NV is then required to finalize the draft update by April 30 of each year. In accordance with the FFCAct CO, each Annual Update will bring the STP current to the end of the previous federal fiscal year (FY). In addition, this update contains information through April 3, 1998, for completeness. The Annual Update will provide a summary of the current status of DOE/NV's progress in implementing the STP as required by the $\mathrm{CO}$, including proposed revisions, technology development, funding and other concerns that may affect the implementation of the STP.

The following Nevada Test Site (NTS) waste streams are discussed in the Annual Update:
a. Polychlorinated Biphenyl (PCB) Soil
b. Lead-Contaminated Soil
c. Bulk Lead Waste
d. Solvent Sludge (Area 12)
e. Treatability Test Facility (TTF) Solvent
f. Cotter Concentrate (Population A)
g. Cotter Concentrate (Population B)
h. Mixed Transuranic (MTRU) Waste

The following waste streams were originally believed to be MW streams requiring treatment but are no longer considered $\mathrm{MW}$, have been shipped for treatment and/or disposal, and have been closed or deleted from the FFCAct CO and STP. The waste streams were reported in the Background Volume of the STP for future reference and are not included in the Annual Update. 
Location of documentation on the status for these waste streams is provided in parenthesis.

a. Pico Fluor (miscellaneous correspondence)

b. Analytical Services Department Solvent (miscellaneous correspondence)

c. Basic Environmental Compliance and Monitoring Program (BECAMP) Scintillation Vials (Letter from NDEP to DOE/NV dated November 17, 1995)

d. BECAMP Scintillation Vial-Associated Waste (Letter from NDEP to DOE/NV dated November 17, 1995)

e. Shipping Cask (Letter from NDEP to DOE/NV dated September 13, 1996)

f. Lead-Contaminated Soil

- Eight boxes $\left(16.33 \mathrm{~m}^{3}\right.$ ) shipped as Low-level Waste (LLW) (Letter from NDEP to DOE/NV dated March 18, 1997)

MTRU waste information reported in the Annual lJpdate meets the annual reporting requirement set forth in the Settlement Agreement between the NDEP and DOE/NV.

\subsection{Framework for Developing the Annual Update}

The framework for developing the Annual Update generally follows the framework of the STP: Information reported in the STP is divided into two volumes. However, for clarity, the information required in the Background and Plan Volumes to the Annual Update has been combined.

\subsection{STP-Covered Mixed Waste}

This section includes the current inventory of MW stored at the NTS that is covered under the STP and the FFCAct CO.

\subsection{PCB Soil}

This waste stream (NT-W005) was originally contained in a 30-gallon drum holding $0.11 \mathrm{~m}^{3}$ of soil and compactable trash (personal protective equipment (PPE), and rags) and exhibiting not only PCB but also the hazardous constituents methylene chloride, acetone, toluene, and 1,1,1trichloroethane. The U.S. Environmental Protection Agency (EPA) waste codes of F001, F003, and F005 were applied.

On November 19,1996 , the soil portion $\left(0.01 \mathrm{~m}^{3}\right.$ - a three-liter sample) was shipped to the DOE Oak Ridge Toxic Substance Control Act (TSCA) Incinerator Facility for analysis. The TSCA Incinerator Facility used the entire sample in their analysis procedure. A request to the Laboratory for documentation on the destructive analysis used has been initiated. Upon receipt of this documentation, this portion will be requested for closure from the STP. 
The remaining portion of the PCB Soil waste stream stored on the Transuranic Waste Storage $\mathrm{Pad}$ (TRU Pad) consists of compactable trash $\left(0.10 \mathrm{~m}^{3}\right)$. The compactable trash portion of this waste stream was originally referenced in the STP and continues to carry the waste codes (F001, F003, and F005) that were associated with the soil portion. NDEP concurred on this waste stream determination, made through process knowledge, via a letter dated March 16, 1998.

The compactable trash is planned to be treated at the DOE Oak Ridge TSCA Incinerator Facility. The PCB Soil associated compactable trash has been placed on the TSCA Incinerator Facility FY99 Burn Plan but shipment has not been scheduled. DOE Oak Ridge granted written approval to place this waste stream on the TSCA Facility FY99 Burn Plan on June 25, 1997. The compactable trash portion of the PCB Soil waste stream continues to be managed on the TRU Pad as MW.

\subsubsection{PCB Soil Schedule (Compactable Trash)}

\begin{tabular}{|c|c|}
\hline $\begin{array}{l}\text { Complete All Additional Waste Characterization Required by } \\
\text { Receiving Site's WAC (STP/CO milestone) }\end{array}$ & $\begin{array}{l}\text { DEADLINE: December } 31,1996 \\
\text { COMPLETED: November } 19,1996\end{array}$ \\
\hline $\begin{array}{l}\text { Receive Written Approval of Acceptance from Receiving Site } \\
\text { (STP/CO milestone) }\end{array}$ & $\begin{array}{l}\text { DEADLINE: June } 30,1997 \\
\text { COMPLETED: June } 25,1997\end{array}$ \\
\hline $\begin{array}{l}\text { If Waste Rejected, Initiate Revision Process (STP/CO } \\
\text { milestone) }\end{array}$ & $\begin{array}{l}\text { DEADLINE:- July } 31,1997 \\
\text { Not Applicable }\end{array}$ \\
\hline 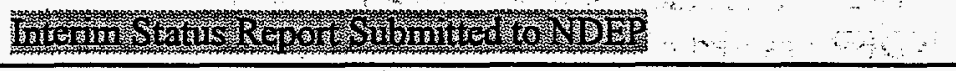 & 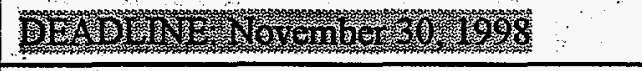 \\
\hline 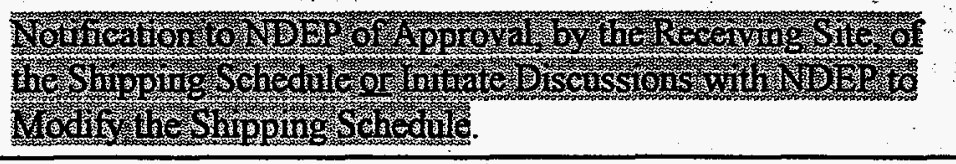 & DEADLINE: February 26, 1999 \\
\hline $\begin{array}{l}\text { Initiate Preparation of Waste for Shipment if Approved } \\
\text { (STP/CO milestone) }\end{array}$ & $\begin{array}{l}\text { DEADLINE: In accordance with } \\
\text { receiving site approved schedule }\end{array}$ \\
\hline Complete Shipment of Waste & $\begin{array}{l}\text { NTERIM ACTIVITY DATE: } \\
\text { Dependent upon outcome of negotiations } \\
\text { with appropriate parties }\end{array}$ \\
\hline
\end{tabular}

\subsection{Lead-Contaminated Soil}

The Lead-Contaminated Soil waste stream consists of soil $\left(31.62 \mathrm{~m}^{3}\right)$ from the Area 3 Field Operations Department (FOD) (NT-W019, 29.8m³), the NTS T2 Site (NT-W019, NT-W020, $1.0 \mathrm{~m}^{3}$ ), Area $12\left(\mathrm{NT}-W 019,0.62 \mathrm{~m}^{3}\right)$, and the Area 27. Explosive Ordnance Disposal (EOD) Unit (NT-W021, 0.20 $\mathrm{m}^{3}$ ). 
Portions of the above waste streams were combined with similar wastes from Federal Facility Agreement Consent Order (FFACO) corrective action units (CAU) 08-26-02 (Area 8, 0.02 $\mathrm{m}^{3}$ ) and CAU 25-26-15 (Area 25, 0.02 $\mathrm{m}^{3}$ ) which otherwise would have been regulated under the Mutual Consent Agreement (MCA).

In a letter to DOE/NV dated March 18, 1997, NDEP concurred with the DOE/NV assertion that eight boxes $\left(16.33 \mathrm{~m}^{3}\right)$ were no longer $\mathrm{MW}$ and agreed to close this portion of the waste stream from the FFCAct CO. On July 10, 1997, the eight boxes of LLW. were shipped to the NTS Area 5 Radioactive Waste Management Site (RWMS) for disposal.

The Area 27 EOD soil contained in one 55 -gallon drum $\left(0.20 \mathrm{~m}^{3}\right)$ was originally thought to be contaminated with lead, radionuclides, and barium. Upon further characterization, it was determined to be hazardous waste. NDEP concurrence was received on August 11, 1997, and on November 5, 1997, the Area 27 EOD hazardous waste soil was shipped off-site for disposal. This portion is requested for closure from the STP in Section 3.0 of this Annual Update.

Seven B-25 boxes $\left(15.13 \mathrm{~m}^{3}\right)$ were initially characterized as MW with lead above the Toxicity Characterization Leaching Procedure (TCLP) limits established by RCRA: Stabilization at Envirocare had been the preferred option for treatment of this waste stream. However, the seven B-25 boxes of $M W$ containing lead shot, lead fines, and soil, did not meet the waste acceptance criteria (WAC) for macroencapsulation at Envirocare. In addition, Envirocare's proposed stabilization facility was not yet available. After additional review of the characterization data, it was determined that three of the remaining seven $\mathrm{B}-25$ boxes did not have properties of $\mathrm{MW}$ based on the NTS standards for radionuclides. NIJEP granted concurrence via letter dated August 11, 1997, and the three B-25 boxes $\left(6.26 \mathrm{~m}^{3}\right)$ were shipped off-site for hazardous waste disposal on November 5, 1997. This portion is requested for closure from the STP in Section 3.0 of this Annual Update.

The only remaining MW is contained in four B-25 boxes $\left(8.87 \mathrm{~m}^{3}\right)$. Stabilization at a RCRApermitted off-site facility is currently being pursued for the soil contaminated with lead and radionuclides. The original FFCAct STP/CO deadline for shipping the remaining B-25 boxes of MW was September 30, 1997. In a letter dated July 31, 1997, DOE/NV requested a revision of this deadline due to problems contracting with the preferred treatment vendor. NDEP responded in a letter dated August 11,1997, requesting more information and a new schedule. On September 17, 1997, a response letter with a new, revised schedule was sent to NDEP. After discussion at a DOE/NV and NDEP September 17, 1997, meeting, DOE/NV sent another letter dated October 9, 1997. This letter requested an extension of the deadline for shipping this waste, and provided additional information about the waste and appropriate treatment technologies. Based on discussion at the FFCAct First Quarter Meeting on November 5, 1997, another letter dated December 2, 1997, was sent to NDEP providing an revised action schedule and requesting that the September 30,1997, deadline be held in ateyance. NDEP concurred on the abeyance and new schedule via letter dated December 19, 1997 as shown in Section 2.2.1 Revised Schedule. 
Envirocare declined DOE/NV access to perform an on-site audit of their treatment facility. A Request for Proposal (RFP) was sent January 8, 1998, to nine vendors. Three vendors responded to the RFP. A technical review has been completed and recommendations have been forwarded to procurement. The next action for DOE $/ \mathrm{NV}$ is to submit a processing schedule or request abeyance for shipping by May 29, 1998 to NDEP.

\subsubsection{Lead-Contaminated Soil Schedule}

\begin{tabular}{|c|c|}
\hline $\begin{array}{l}\text { Complete Soil Screening and Initiate Sampling of Screened } \\
\text { Soil (STP/CO milestone) }\end{array}$ & $\begin{array}{l}\text { DEADLINE: September 30, } 1996 \\
\text { COMPLETED: August 22, } 1996\end{array}$ \\
\hline $\begin{array}{l}\text { Complete All Additional Waste Characterization Required by } \\
\text { Envirocare WAC }\end{array}$ & $\begin{array}{l}\text { DNTERIM ACTIVITY DATE: } \\
\text { April 1, } 1997 \\
\text { CANCELED: Pursuing Alternate } \\
\text { Treatment Options }\end{array}$ \\
\hline $\begin{array}{l}\text { Receive Written Approval of Acceptance from Envirocare } \\
\qquad\end{array}$ & $\begin{array}{l}\text { INTERIM ACTIVITY DATE: } \\
\text { May 30, } 1997 \\
\text { CANCELED: Pursuing Alternate } \\
\text { Treatment Options }\end{array}$ \\
\hline $\begin{array}{l}\text { Submit Schedule for Processing Backlogged Waste or Initiate } \\
\text { Revision.Process Detailed in NTS FFCAct CO (STP/CO } \\
\text { milestone) }\end{array}$ & $\begin{array}{l}\text { DEADLNE: July } 31,1997 \\
\text { HELD IN ABEYANCE }\end{array}$ \\
\hline $\begin{array}{l}\text { Complete Shipment of Waste to Receiving Site (STP/CO } \\
\text { milestone) } \\
\text { - Eight B-25 boxes of lead soil }\left(16.33 \mathrm{~m}^{3}\right) \text { shipped to the } \\
\text { NTS Area } 5 \text { RWMS for disposal } \\
\text { - Three B-25 boxes of lead soil }\left(6.26 \mathrm{~m}^{3}\right) \text { shipped off-site as } \\
\text { hazardous waste } \\
\text { - One drum of Area } 27 \text { EOD soil }\left(0.2 \mathrm{~m}^{3}\right) \text { shipped off-site as } \\
\text { hazardous waste }\end{array}$ & $\begin{array}{l}\text { DEADLINE: September } 30,1997 \\
\text { HELD IN ABEYANCE } \\
\text { NDEP concurred December 19, } 1997 \\
\text { COMPLETED: July } 10,1997 \\
\text { COMPLETED: November } 5,1997 \\
\text { COMPLETED: November } 5,1997\end{array}$ \\
\hline
\end{tabular}




\section{Revised Schedule: Lead-Contaminated Soil}

Envirocare is Approved as a Qualified Treatment Vendor by BN or a Request for Proposal (RFP) will be Issued Asking for Proposals from Other Qualified Vendors (milestone)

If Envirocare is Approved as a Qualified Treatment Vendor, a Processing Schedule for Treatment at Envirocare will be Submitted (milestone)

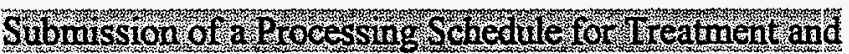
Disposal, or a Request to NDEP for Continued Stor ag t if 1 Request for Contirued Storag is nade, Steps WU be bken

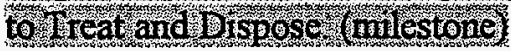

DEADLINE: January 30, 1998

COMPLETED: January 8, 1998 RFP Issued

DEADLINE: March 31, 1998

Not Applicable

DEADLINE: May 29, 1998

\subsection{Bulk Lead Waste}

Approximately 70 percent of the bulk lead, which included the Defense Special Weapons Agency (DSWA) formerly the Defense Nuclear Agency (DNA) Lead Cylinders (NT-W020,0.21 $\mathrm{m}^{3}$ ), the Junior Hot Cell Mesh (NT-W022, 0.37 $\mathrm{m}^{3}$ ), the Area 25 Test Cell C (NT-W023, 0.01 $\mathrm{m}^{3}$ ), and a portion of T2 Lead (NT-W019, 2.10 $\mathrm{m}^{3}$ ) was shipped off-site as MW to Envirocare on September 27,1996 , for treatment and disposal. This portion is requested for closure from the STP in Section 3.0 of this Annual Update.

The spent batteries (NT-W020,0.076 $\mathrm{m}^{3}$ ) underwent additional sampling and analysis, as requested by Envirocare, in November 1996. They were added to bulk lead waste from FFACO CAU 386 Site \#04-26-03 $\left(0: 10 \mathrm{~m}^{3}\right)$ that was to be managed under the MCA. This waste, comprised of four percent of the total bulk lead waste stream, was shipped to Envirocare as MW on April 2, 1997, for treatment and disposal. This portion is requested for closure from the STP in Section 3.0 of this Annual Update.

The T2 lead cylinders (NT-W020, $1.0 \mathrm{~m}^{3}$ ) exceeded Envirocare's size constraint for macroencapsulation. DOE contended the $\mathrm{T} 2$ lead cylinders could be decontaminated and recycled as scrap metal and requested their redesignation as such from NDEP. NDEP concurred with DOE's request to redesignate the $T 2$ lead cylinders as recyclable material in a letter dated April 10,1997 . As a condition of NDEP concurrence, IOOE/NV continued to manage the T2 lead cylinders as a MW until they were shipped to Scientific Ecology Group (SEG) in Tennessee. The T2 lead cylinders, comprised of 26 percent of the total bulk lead waste stream, were shipped to SEG on July 2, 1997. Confirmation surveys have been done to demonstrate that the decontamination efforts were effective. Documentation regarding SEG receipt of $\mathrm{T} 2$ lead cylinders was forwarded to NDEP on November 28, 1997. This portion is requested for closure from the STP in Section 3.0 of this Annual Update. 
The only waste remaining from this waste stream is compactible trash and PPE $\left(0.42 \mathrm{~m}^{3}\right)$ generated during sampling and repackaging operations. Sampling of this waste was completed November 20, 1997 and declared a MW by DOE/NV in a letter dated February 23, 1998. NDEP concurred with the schedule via letter dated March 16, 1998 as shown below in Section 2.3.1.3. The next action for DOE/NV is to submit a disposition schedule to NDEP by May 29, 1998.

\subsubsection{Bulk Lead Waste Schedule}

\begin{tabular}{|l|l|}
\hline $\begin{array}{l}\text { Complete All Additional Waste Characterization Required by } \\
\text { Receiving Facility (STP/CO milestone) }\end{array}$ & $\begin{array}{l}\text { DEADLINE: June 30, 1996 } \\
\text { COMPLETED: June 6; 1996 }\end{array}$ \\
\hline $\begin{array}{l}\text { Initiate Preparation of Waste for Shipment, If Approved, or } \\
\text { Initiate Revision Process Detailed in the FFCAct CO } \\
\text { (STP/CO milestone) }\end{array}$ & $\begin{array}{l}\text { DEADLINE: September 30, 1996 } \\
\text { COMPLETED: Waste Shipped } \\
\text { September 27, 1996 }\end{array}$ \\
\hline $\begin{array}{l}\text { Submit Schedule of Processing Backlogged Waste Based } \\
\text { Upon Completion of Demonstration Project (STP/CO } \\
\text { milestone) }\end{array}$ & $\begin{array}{l}\text { DEADLINE: December 31, 1996 } \\
\text { COMPLETED: December 31, 1996 }\end{array}$ \\
\hline Complete Shipment of Waste & - \\
& $\begin{array}{l}\text { INTERIM ACTIVITY DATE: } \\
\text { February 28, 1997 } \\
\text { COMPLETED: September 27, 1996 }\end{array}$ \\
\hline
\end{tabular}

\subsubsection{1 ... Spent Batteries Schedule}

\begin{tabular}{|l|l|}
\hline $\begin{array}{l}\text { Initiate Contract with Permitted MW Treatment Facility to } \\
\text { Treat Spent Batteries (milestone) }\end{array}$ & $\begin{array}{l}\text { DEADLINE: April 1,1997 } \\
\text { COMPLETED: March 10, 1997 }\end{array}$ \\
\hline $\begin{array}{l}\text { Initiate Preparation of Spent Battery Shipment to Receiving } \\
\begin{array}{l}\text { Site After Formalizing Contract with Designated Waste } \\
\text { Treatment Facility (milestone) }\end{array}\end{array}$ & $\begin{array}{l}\text { DEADLINE: Within 60 Days of } \\
\text { Successful Negotiation of Contract } \\
\text { COMPLETED: April 2, 1997 }\end{array}$ \\
\hline Complete Spent Battery Shipment (milestone) & $\begin{array}{l}\text { DEADLINE: Within 30 Days of } \\
\text { Initiating Preparation of Waste Shipment } \\
\text { COMPLETED: April 2, 1997 }\end{array}$ \\
\hline
\end{tabular}




\subsubsection{T2 Lead Cylinders Schedule}

Initiate Contract with Designated Decontamination Facility for

T2 Lead Reclamation (milestone)
DEADLINE: Within 60 Days of NDEP Concurrence that Lead Cylinders can be Categorized as Recyclable Scrap Metal NDEP Concurrence: April 10, 1997 DEADLINE: June 9, 1997 COMPLETED: May 1, 1997 Waste Shipped: July 2, 1997

\subsubsection{Compactible Trash and PPE Schedule}

\begin{tabular}{|c|c|}
\hline Characterize Waste as Hazardous, LLW, or MW & $\begin{array}{l}\text { February 27, } 1998 \\
\text { COMPLETED: February 23, } 1998 \\
\text { Waste Declared MW }\end{array}$ \\
\hline $\begin{array}{l}\text { If Waste is Characterized as Hazardous or LLW, DOENV } \\
\text { will provide NDEP with a Letter for Concurrence }\end{array}$ & $\begin{array}{l}\text { March 31, } 1998 \\
\text { Not Applicable }\end{array}$ \\
\hline 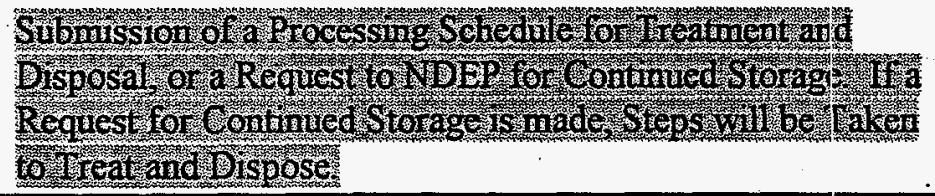 & DEANIEIIISMay 29, 1998 \\
\hline
\end{tabular}

\subsection{Area 12 Solvent Sludge}

Approximately $0.11 \mathrm{~m}^{3}$ of spent solvent sludge generated from a solvent recovery operation in Area 12 was originally stored in two containers or. the TRU Pad.: DOE/NV reviewed the radioisotope data for the Area 12 Solvent Sludge waste stream (NT-W002) against the NTS Performance Objective for Certification of Nonradioactive Hazardous Waste (POC) and confirmed the radioactivity exhibited by the Solvent Sludge fell below the POC limits. As reported in the November 29, 1996, letter to NDEP from DOE/NV, the Area 12 Solvent Sludge $(0.03 \mathrm{~m} 3)$ is hazardous waste bearing the EPA waste codes F001 and D008 without a radioactive component and, therefore, not MW. The NDEP concurred with DOE/NV's assertion in their written reply to DOE/NV dated January 13, 1997. In accordance with Part XI.3 of the FFCAct $\mathrm{CO}$, the Area 12 Solvent Sludge was moved to the Hazardous Waste Storage Pad on January 30 , 1997, and was shipped off-site for disposal as hazirirdous waste on June 3, 1997.

The waste stream also consisted of three paper $18 \times 3$ inch filters and one paper oil $4 \times 6$ inch filter $\left(0.08 \mathrm{~m}^{3}\right)$. The analytical results for this waste were reviewed, and the three filters were 
Nevada Test Site

Site Treatment Plan - Final Annual Update

April 1998

determined to be hazardous waste and not MW. The $4 \times 6$ inch filter was determined to be nonhazardous but due to economical reasons, was left in the drum with the other three filters. In a letter dated August 11, 1997, NDEP concurred with DOE/NV that the filters were considered part of the Area 12 Solvent Sludge waste and should also be disposed of as hazardous waste. The Area 12 Solvent Sludge filters were transported from the TRU Pad to the Hazardous Waste Storage Pad on June 19, 1997, and managed as hazardous waste until they were shipped off-site for disposal on November 5, 1997.

This entire waste stream is requested for deletion from the STP in Section 3.0 of this Annual Update.

\subsubsection{Area 12 Solvent Sludge Schedule}

\begin{tabular}{|l|l|}
\hline $\begin{array}{l}\text { Complete All Additional Waste Characterization Required by } \\
\text { Receiving Site's WAC (STP/CO milestone) }\end{array}$ & $\begin{array}{l}\text { DEADLINE: December 31, 1996 } \\
\text { COMPLETED: November 19,1996 }\end{array}$ \\
\hline $\begin{array}{l}\text { Receive Written Approval of Acceptance from Receiving Site } \\
\text { (STP/CO milestone) }\end{array}$ & $\begin{array}{l}\text { DEADLINE: June 30, 1997 } \\
\text { CANCELED: Waste determined to be } \\
\text { Hazardous Only }\end{array}$ \\
\hline $\begin{array}{l}\text { If Waste Rejected, Initiate Revision Process Detailed in NTS } \\
\text { FFCAct CO (STP/CO milestone) }\end{array}$ & $\begin{array}{l}\text { DEADLINE: July 31,1997 } \\
\text { CANCELED: Waste determined to be } \\
\text { Hazardous Only }\end{array}$ \\
\hline Initiate Preparation of Waste for Shipment, if Approved & $\begin{array}{l}\text { In accordance with receiving site } \\
\text { approved schedule } \\
\text { CANCELED: Waste determined to be } \\
\text { Hazardous Only }\end{array}$ \\
\hline $\begin{array}{l}\text { Complete Shipment of Waste } \\
\text { INTERIM ACTIVITY DATE: } \\
\text { COMPLETED: June 3, 1997 and } \\
\text { November 5, 1997 }\end{array}$ \\
\hline
\end{tabular}

\subsection{TTF Solvent}

This waste stream (NT-W015) containing approximately $0.21 \mathrm{~m}^{3}$ of liquid was discovered in a drum that emitted a strong odor when opened. The liquid was sampled for the first time on August 14, 1994; results indicated the presence of acetone (F003) and Cesium-137. The liquid was again sampled on August 30,1995, to determine the flash point. Results indicated a flash point of $82^{\circ} \mathrm{F}$ which added the EPA waste code D001. Samples of this waste were shipped for analysis on November 19, 1996, to the Lockheed Martin Energy Systems (LMES) laboratory in Oak Ridge, Tennessee. The LMES analyses contradicted results from previous analyses done during sampling efforts. LMES found that the flashpoint of the TTF Solvent was above $200^{\circ} \mathrm{F}$. 
This would mean that the liquid is not a D001 coded waste. LMES also determined that the liquid is not a organic solvent, but an acidic aqueous solution, exhibiting corrosivity and the EPA waste code D002. LMES also determined the EPA waste codes D006, D008, D010, and F001 should be applied. Incineration at the DOE Oak Fidge TSCA Incinerator Facility was considered to be the preferred treatment option.

DOE Oak Ridge granted written approval of this waste stream on June 25, 1997. The waste has been included on the DOE Oak Ridge TSCA Incinerator Facility FY99 Burn Plan but has not been scheduled for shipment. However, after further investigation, it has been determined that the TTF Solvent according to RCRA regulation is not suitable for the TSCA Incinerator Facility. The Statement of Policy under RCRA 40 CFR 263.3 clarifies the application of the LDR prohibition on dilution to combustion of certain inorganic metal-bearing hazardous wastes. Because combustion normally does not represent effective treatment of this waste, such burning can be considered impermissible dilution.

Per RCRA 40 CFR 262.11, the waste will be coded as D001, D002, D006, D008, and D010. There is no reason to believe or suspect the trace amounts of organics were used as solvents or degreasers since we do not know the process from which the waste was derived eliminating the need for the above stated F001 code. The liquid continues to be managed on the TRU Pad as MW. Options for the treatment (elementary neutralization / stabilization) of this waste stream are currently being pursued. A treatability study may need to be conducted prior to treating of this waste.

\subsubsection{TTF Solvent Schedule}

\begin{tabular}{|c|c|}
\hline $\begin{array}{l}\text { Complete All Additional Waste Characterization Required by } \\
\text { Receiving Site's WAC (STP/CO milestone) }\end{array}$ & $\begin{array}{l}\text { DEADLINE: December } 31,1996 \\
\text { COMPLETED: November } 19,1996\end{array}$ \\
\hline $\begin{array}{l}\text { Receive Written Approval of Acceptance from Receiving Site } \\
\text { (STP/CO milestone) }\end{array}$ & $\begin{array}{l}\text { DEADLINE: June } 30,1997 \\
\text { COMPLETED: June } 25,1997\end{array}$ \\
\hline $\begin{array}{l}\text { If Waste Rejected, Initiate Revision Process Detailed ir: NTS } \\
\text { FFCAct CO (STP/CO milestone) }\end{array}$ & $\begin{array}{l}\text { DEADLINE: July } 31,1997 \\
\text { CANCELED: Waste not Rejected }\end{array}$ \\
\hline 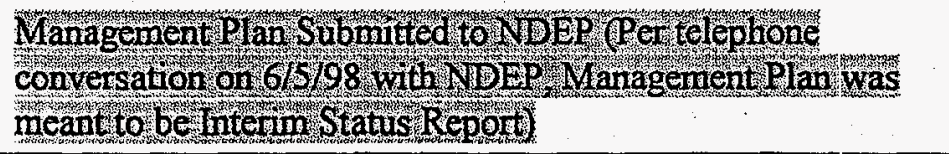 & DEADLNE November 30.1998 \\
\hline 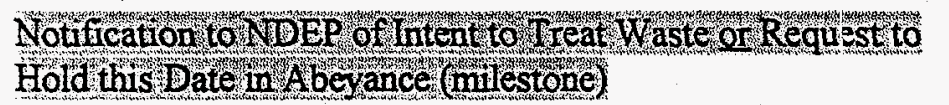 & DEADLINE: April 16, 1999 \\
\hline
\end{tabular}


Nevada Test Site

Initiate Preparation of Waste for Shipment, if Approved (STP/CO milestone)

Complete Shipment of Waste
DEADLINE: In accordance with receiving site approved schedule Has been entered on FY99 TSCA Burn Plan but not scheduled for shipment

INTERIM ACTIVITY DATE:

Dependent upon outcome of negotiations with appropriate parties

\subsection{Cotter Concentrate}

In 1987, Cotter Concentrate, a sludge-like residue resulting from uranium ore processing, was sent to the NTS for storage in 1,245 55-gallon drums from the DOE Mound Plant in Miamisburg, Ohio. In January 1994, the state of Nevada approved a sampling plan for characterizing the Cotter Concentrate. Results showed selenium to be the major RCRA constituent. The sampling and analysis plan split the 1,245 drums into two separate populations. Population $A$ consisted of 1,236 drums suspected of containing only inorganic constituents and radionuclides. Population $B$ consisted of nine drums that were suspected of containing inorganic constituents and radionuclides as well as organic constituents. One additional drum of Population $B$ was discovered during repackaging. This drum, stored with the Population A material, was listed incorrectly on the original inventory that was compiled by the Cotter Corporation. Therefore, a total of 9 drums of Population B existed instead of eight drums as previously stated in the STP. This brought the total number of drums received at the NTS to 1245 instead of 1244 as previously stated.

\subsubsection{Cotter Concentrate (Population A)}

Originally an estimated $260 \mathrm{~m}^{3}$ of Cotter Concentrate (Population A, NT-A009) with the RCRA waste codes D002 and D010 were stored at the NTS. This volume was based on the assumption that the 123655 -gallon drums were full. During the process of repackaging, each drum was weighed and the actual volume per drum was calculated using the known density of the Cotter material. The actual total volume of Population A was calculated as $197 \mathrm{~m}^{3}$. Treatment at an onsite treatment facility was the option preferred to manage this material. Cotter Concentrate (Population A) was managed with Cotter Concentrate (Population B) as described in Section 2.7.

\subsubsection{Cotter Concentrate (Population A) Schedule}

Provide Results of Treatability Study to the State of Nevada (STP/CO milestone)
DEADLINE: April 30, 1996

COMPLETED: April 29, 1996 


\begin{tabular}{|c|c|}
\hline Issue RFP for Pilot-Scale Study or Initiate Alternative Option & $\begin{array}{l}\text { INTERIM ACTIVITY DATE: } \\
\text { June 30, } 1996 \\
\text { COMPLETED: RFP Issued for Study }\end{array}$ \\
\hline Award RFP & $\begin{array}{l}\text { INTERIM ACTIVITY DATE: } \\
\text { August 31, } 1996 \\
\text { CANCELED: Revised Schedule } \\
\text { Approved }\end{array}$ \\
\hline Initiate Pilot-Scale Study & $\begin{array}{l}\text { INTERIM ACTIVTTY DATE: } \\
\text { October } 31,1996 \\
\text { CANCELED: Revised Schedule } \\
\text { Approved }\end{array}$ \\
\hline Complete Pilot-Scale Study : & $\begin{array}{l}\text { INTERIM ACTIVITY DATE: } \\
\text { December 30, } 1996 \\
\text { CANCELED: Revised Schedule } \\
\text { Approved }\end{array}$ \\
\hline $\begin{array}{l}\text { Provide Treatment Results from Pilot-Scale Study to state of } \\
\text { Nevada (STP/CO milestone) }\end{array}$ & $\begin{array}{l}\text { DEADLINE: February } 28,1997 \\
\text { CANCELED: Revised Schedule } \\
\text { Approved }\end{array}$ \\
\hline $\begin{array}{l}\text { If Pilot-Scale Study Successful, Submit Request to Modify } \\
\text { RCRA Part B Permit to the state of Nevada or Initiate } \\
\text { Revision Process Detailed in NTS FFCAct CO (STP/CO } \\
\text { milestone) }\end{array}$ & $\begin{array}{l}\text { DEADLINE: April 30, } 1997 \\
\text { CANCELED: Revised Schedule } \\
\text { Approved }\end{array}$ \\
\hline State Approves Permit Modification (assumption) & $\begin{array}{l}\text { At the discretion of the state of Nevada } \\
\text { CANCELED: Revised Schedule } \\
\text { Approved }\end{array}$ \\
\hline $\begin{array}{l}\text { Award Proposal, Assemble Treatment System, and Initiate } \\
\text { Treatment System Testing (STP/CO milestone) }\end{array}$ & $\begin{array}{l}\text { DEADLINE: Within } 12 \text { months of } \\
\text { completion of successful system testing } \\
\text { CANCELED: Revised Schedule } \\
\text { Approved }\end{array}$ \\
\hline $\begin{array}{l}\text { Complete Successful System Testing, and Submit Schedule } \\
\text { for Processing Backlogged Volumes of Cotter Concentrate } \\
\text { (STP/CO milestone) }\end{array}$ & $\begin{array}{l}\text { DEADLINE: Within } 6 \text { months of } \\
\text { completion of previous milestone } \\
\text { CANCELED: Revised Schedule } \\
\text { Approved }\end{array}$ \\
\hline Initiate Processing of Cotter Concentrate & $\begin{array}{l}\text { INTERIM ACTIVITY DATE: } \\
\text { Within } 3 \text { months of completion of } \\
\text { successful system testing } \\
\text { CANCELED: Revised Schedule } \\
\text { Approved }\end{array}$ \\
\hline
\end{tabular}


Nevada Test Site

INTERIM ACTIVITY DATE:

Date will be provided upon submittal of schedule for processing backlogged waste

CANCELED: Revised Schedule Approved

\subsubsection{Cotter Concentrate (Population B)}

Originally an estimated $1.4 \mathrm{~m}^{3}$ of Cotter Concentrate (Population B, NT-B009) with the RCRA waste codes F001, F005, D002, and D010 were stored in eight 55-gallon drums at the NTS. This volume was based on the assumption that the eight 55-gallon drums were full. During the process of repackaging, each drum was weighed and the actual volume per drum was calculated using the known density of the Cotter material. The actual total volume of Population B, all nine drums, was calculated as $0.9 \mathrm{~m}^{3}$. Treatment at the DOE Oak Ridge TSCA Incinerator Facility was the preferred treatment option for this waste stream. Cotter Concentrate (Population B) was managed with Cotter Concentrate (Population A), as described in Section 2.7.

In a January 13,1997 , letter from NDEP to DOE/NV, NDEP concurred with the DOE $\mathrm{NV}$ to remove the F001 and F005 codes on the basis that the Cotter Concentrate was a process waste contaminated with solvents.

\subsubsection{Cotter Concentrate (Population B) Schedule}

\begin{tabular}{|l|l|}
\hline $\begin{array}{l}\text { Complete All Additional Waste Characterization Required by } \\
\text { Receiving Site's WAC (STP/CO milestone) }\end{array}$ & $\begin{array}{l}\text { DEADLINE: December 31, 1996 } \\
\text { CANCELED: Revised Schedule } \\
\text { Approved }\end{array}$ \\
\hline $\begin{array}{l}\text { Receive Written Approval of Acceptance from Receiving Site } \\
\text { (STP/CO milestone) }\end{array}$ & $\begin{array}{l}\text { DEADLINE: June 30, 1997 } \\
\text { CANCELED: Revised Schedule } \\
\text { Approved }\end{array}$ \\
\hline $\begin{array}{l}\text { If Waste Rejected, Initiate Revision Process (STP/CO } \\
\text { milestone) }\end{array}$ & $\begin{array}{l}\text { DEADLINE: July 31, 1997 } \\
\text { CANCELED: Revised Schedule } \\
\text { Approved }\end{array}$ \\
\hline $\begin{array}{l}\text { Initiate Preparation of Waste for Shipment, If Approved } \\
\text { (STP/CO milestone) }\end{array}$ & $\begin{array}{l}\text { DEADLINE: In accordance with } \\
\text { receiving site approved schedule } \\
\text { CANCELED: Revised Schedule } \\
\text { Approved }\end{array}$ \\
\hline
\end{tabular}


Complete Shipment of Waste

\subsection{Cotter Concentrate (Population A \& B)}

DOE/NV determined that transferring Cotter Concentrate for additional uranium extraction by the uranium processing mill operated by International Uranium Corporation (IUC), formerly Energy Fuels Nuclear, Inc. (EFN) instead of treating the rvaste on-site would expedite disposal of Cotter Concentrate by two years and recycle approximately $198 \mathrm{~m}^{3}$ of material. This translated into a significant reduction in overall cost, resources, and worker exposure. Because IUC intended to reprocess the Cotter material for its intended purpose as concentrated uranium ore, DOE/NV contended that this waste stream should be reclassified as alternate feed material and requested that NDEP delete it from the STP and the FFCAc: CO.

DOE/NV and NDEP agreed during the FFCAct FY97 First Quarter Meeting held November 13, 1996, to hold the STP interim activity dates and milestones, and the FFCAct CO deadlines for Cotter Concentrate (Population A \& B) in abeyance to provide DOE/NV the opportunity to pursue recycling at IUC, and IUC to receive approval of their Nuclear Regulatory Commission (NRC) license amendment to accept Cotter Concentrate. Accordingly, both parties agreed that the Cotter Concentrate deadlines would be held in abeyance. The STP and FFCAct CO schedules were modified to reflect this agreement.

While awaiting the approval of IUC's NRC license amendment to accept the Cotter Concentrate as alternate feed, NDEP maintained the waste should continue to be managed as MW in accordance with the FFCAct $\mathrm{CO}$ because it was still a characteristic hazardous waste. In a letter dated January 13, 1997, NDEP agreed that, upon receipt of documentation that the NRC license amendment had been approved, the State would formally declare the Cotter Concentrate a nonRCRA-regulated material and that it would be available for release as feed material to IUC: Cotter Concentrate would then be deleted from the STP and the FFCAct CO.

The NRC license amendment was approved on April 4, 1997. Repacking of Cotter (Population A and B) was initiated on April 25, 1997, and the first shipment was made on May 29, 1997. A total of 28 shipments were required to transport the entire quantity of material to the IUC facility. Two to three shipments were made per week with a total of approximately 45 drums on each shipment. The final day of packaging was conducted on July 31,1997 , and the final shipment from the NTS to IUC was made on August 12, 1997. A total of 1248 drums were shipped which included 1239 drums of Population A and nine drums of Population B. Three additional drums of 
population A material were generated from sample material taken from the original 1236 drums and placed in various sizes of sample bottles. These samples were collected and stored in the three drums for anticipated future use by treatment vendors responding to the RFP. These additional drums do not represent an increase in the total volume of Cotter Concentrate material. IUC began processing the Cotter material on September 4, 1997. Cotter Concentrate material drums were emptied and fed into the IUC extraction process by the end of December 1997. This portion is requested for deletion from the STP in Section 3.0 of this Annual Update.

The only Cotter Concentrate material remaining at the NTS is the trash and treatability study residue. This new quantity of waste consists of solidified residue generated during the treatability study performed in 1996 and trash generated over the past four years from Cotter Concentrate sampling, treatability study, and overpacking operations $\left(368.06 \mathrm{~m}^{3}\right)$. The subject material could not be sent to IUC because it was not material that could be used for uranium extraction.

The treatability study residual $\left(0.06 \mathrm{~m}^{3}\right)$ consists of Cotter Concentrate residue which had been dried, mixed with cement and water, and then allowed to cure into a stabilized concrete form. These pieces were then used to provide sample material for the TCLP analysis. Based on the results of the TCLP analysis, this material is considered a MW due to the presence of Selenium (D010) above the TCLP regulatory level of $1.0 \mathrm{mg} / \mathrm{L}$ and is currently stored on the TRU Pad. This MW is considered to have been newly generated at the completion of the treatability study and only exhibits the characteristic of toxicity for Selenium. In a letter dated December 19, 1997, DOE/NV received concurrence from NDEP to dispose of this as MW in the Area 5.Radioactive Waste Management Site, Pit 3.

The trash $\left(368.0 \mathrm{~m}^{3}\right)$ consists of treatability study compactible trash $\left(36.0 \mathrm{~m}^{3}\right)$, vermiculite $\left(24.0 \mathrm{~m}^{3}\right)$, and empty wooden boxes $\left(308.0 \mathrm{~m}^{3}\right)$. In accordance with 40 CFR 261.3 , this waste is not considered a hazardous waste. This waste will be managed as LLW and is currently stored at the Area 6 Decontamination Pad,

A letter from DOE/NV to NDEP requesting concurrence on the management and disposal of the Cotter Concentrate trash and treatability study residual was sent November 14, 1997. NDEP concurred on management of this waste in a letter dated December 19, 1997. The trash $\left(368.0 \mathrm{~m}^{3}\right)$ is requested for colosure from the STP in Section 3.0 of this Annual Update due to NDEP concurrence as LLW and therefore, not subject to the STP. The treatability study residual $\left(0.06 \mathrm{~m}^{3}\right)$ is the only remaining volume of this waste stream to be covered by the STP. 
Nevada Test Site.

Site Treatment Plan - Final Annual Update

April 1998

\subsubsection{Revised Schedule: Cotter Concentrate (Population A \& B)}

\begin{tabular}{|l|l|}
\hline Receive Approval of NRC License Amendment & $\begin{array}{l}\text { INTERIM ACTIVITY DATE: } \\
\text { April 30, 1997 } \\
\text { COMPLETED: April 4, } 1997\end{array}$ \\
\hline Initiate Material Loading and Transport (STP/CO milestone) & $\begin{array}{l}\text { DEADLINE: May 30, 1997 } \\
\text { COMPLETED: May 29, 1997 }\end{array}$ \\
\hline Complete Material Transport to IUC (STP/CO milestone) & $\begin{array}{l}\text { DEADLINE: August 29, } 1997 \\
\text { COMPLETED: August 12, } 1997\end{array}$ \\
\hline
\end{tabular}

\subsection{Mixed Transuranic Waste}

There are approximately $617 \mathrm{~m}^{3}$ of MTRU currently stored on the TRU Pad. Examination of the MTRU (non-classified drums containing $350 \mathrm{~m}^{3}$ ) at the NTS Waste Examination Facility (WEF) is on schedule. Construction and operation of the facility was covered under the NTS Environmental Impact Statement Record of Decision that was signed December 10, 1996. Construction of the WEF was completed on June 26, 1997. A pilot demonstration project for visual inspection and repackaging of the MTRU wraste drums was completed on October 9, 1997. The process to characterize the waste will undergo its certification audit in FY98, and characterization is scheduled to begin when certification is granted. A request to revise the deadline to complete pre-characterization activities by June 1,1998 , was formally transmitted to NDEP in a letter dated January 22, 1998. NDEP approved the request with the Revised Schedule below replacing the FFCAct CO deadline of June 1, 1998, via letter dated February 20, 1998.

There are 58 nonstandard waste boxes of MTRU waste currently stored in Area 5 on the TRU Pad. These boxes comprise $267 \mathrm{~m}^{3}$ of the total NTS MTRU inventory. Disposition alternatives for these boxes are currently being investigated by $D O E / N V$.

\subsubsection{Mixed Transuranic Waste Schedule}

\begin{tabular}{|l|l|}
\hline $\begin{array}{l}\text { Submit Work Plan to state of Nevada for TRU Waste } \\
\text { Characterization Project (STP/CO milestone) }\end{array}$ & $\begin{array}{l}\text { DEADLINE: February 29, 1996 } \\
\text { COMPLETED: February 29, 1996 }\end{array}$ \\
\hline $\begin{array}{l}\text { Complete Construction of Facility and Submit Processing } \\
\text { Schedule (STP/CO milestone) }\end{array}$ & $\begin{array}{l}\text { DEADLINE: June 30, } 1997 \\
\text { COMPLETED: June 26, } 1997\end{array}$ \\
\hline
\end{tabular}


Complete Pre-Characterization Activities Required by Waste Isolation Pilot Plant (WIPP) with all Required Information Submitted for Incorporation into the WIPP Waste Information System or Initiate Discussions with state of Nevada if WIPP Does Not Open (STP/CO milestone)

Prepare a Plan to Ship MTRU to WIPP

Provide a Timetable for Submitting a Shipping Schedule
DEADLINE: June 1, 1998

See Revised Schedule below

INTERIM ACTIVITY DATE:

Within 12 months of decision to operate WIPP

INTERIM ACTIVITY DATE:

Within 12 months of decision to operate WIPP

\section{Processing Schedule: Mixed Transuranic Waste}

End Review of Procedure and Operating Capability of Waste Examination Facility (WEF) for Non-Radioactive Material in Drums (STP/CO milestone)

Submit to NDEP an Affirmation that the WEF is Fully Operational and Capable of Initiating Pre-Characterization Activities to meet the June 1,1998 Deadline

Initiate Visual Examination and Repackaging of Radioactive Material in 12 Drums

Complete Examination and Repackaging of Radioactive Material in 12 Drums
December 15, 1997

COMPLETED: September 4, 1997

DEADLINE: December 15, 1997

Established in NDEP letter

September 22, 1997

COMPLETED: December 18, 1997

INTERIM ACTIVITY DATE:

January 30, 1998

COMPLETED: September 22, 1997

INTERIM ACTIVITY DATE:

April 30,1998

COMPLETED: October 9, 1997

\section{Revised Schedule: Mixed Transuranic Waste}

Submit to NDEP Complete Results and Conclusions from the DOE Carlsbad Area Office (CAO) Audit of the Certification of the WEF for Review by NDEP

Submit Shipping Schedule from the DOE/CAO for Processing of the MTRU at WIPP
DEADLINE: September 1, 1998

DEADLINE: September 1, 1998 


\subsection{Summary}

All STP milestones or FFCAct CO deadlines have been met for FY97. In addition, DOE/NV received NDEP concurrence that the September 30, 1997, milestone for shipping the LeadContaminated Soil be held in abeyance until a treatment vendor can be identified and a contract put in place. A NDEP letter dated September 22, 1997, established a December 15, 1997, deadline to submit an affirmation of the WEF operational status. DOE/NV submitted the affirmation on December 18, 1997.

The following is a list of waste streams that have been closed or deleted from the Plan Volume of the STP/CO since it was issued on March 6, 1996:

a. Shipping Cask (Letter from NDEP to DOE/NV dated November 13, 1996)

b. A Portion of the Lead Contaminated Soil $\left(16.33 \mathrm{~m}^{3}\right.$, Letter from NDEP to DOE/NV dated March 18, 1997)

As per this STP Annual Update, DOE/NV is requesting that the following waste steream be deleted from the STP and FFCAct CO in accordance with Part XI of the FFCAct CO:

a. Area 12 Solvent Sludge and associated filters $\left(0.11 \mathrm{~m}^{3}\right)$

The following is a list of waste streams that DOE/NV is requesting closure for in the STP and FFCAct $\mathrm{CO}$ as per this STP Annual Update. Closure indicates NDEP concurrence that DOE/NV no longer has to include these in waste stream status reports. These wastes cannot be requested for deletion until the original waste stream and all its' ancillary components have been dispositioned.

a. A portion of the Lead Contaminated Soil $\left(6.45 \mathrm{~m}^{3}\right)$

b. Contaminated Bulk Lead $\left(3.77 \mathrm{~m}^{3}\right.$, this volume does not include $0.1 \mathrm{~m}^{3}$ of MCA managed Bulk Waste that was also sent for treatment)

c. A Portion of the Cotter Concentrate (Population A, 1239 Drums, $197 \mathrm{~m}^{3}$ )

d. Cotter Concentrate (Population B, 9 Drums, $0.9 \mathrm{~m}^{3}$ )

Coter Concentrate $A$ ssociated Trash $(368.0 \mathrm{~m}$, new volume generated durng sampling and repackaging of the SIP Cotter Concentrate Waste stream)

The following waste streams will continue to be managed under the STP and FFCAct CO during FY98:

a. A portion of the PCB Soil Waste $\left(0.01 \mathrm{~m}^{3}\right)$

b. PCB Soil Associated PPE and Rags $\left(0.1 \mathrm{~m}^{3}\right)$

c. Lead Contaminated Soil $\left(8.87 \mathrm{~m}^{3}\right)$

d. Bulk Lead Associated Compactible Trash $\left(0.42 \mathrm{~m}^{3}\right.$, new volume generated during sampling 
and handling of STP bulk lead waste stream)

e. TTF Solvent $\left(0.21 \mathrm{~m}^{3}\right)$

f. Cotter Concentrate Treatability Study Residual $\left(0.06 \mathrm{~m}^{3}\right.$, new volume generated from Cotter Concentrate Treatability Study)

g. Mixed Transuranic Waste $\left(620 \mathrm{~m}^{3}\right.$, additional volumes may be generated during the repackaging process)

Completion and submittal of this Final Annual Update to NDEP by April 30, 1998, meets the progress reporting requirements for this activity. 